University for Business and Technology in Kosovo

UBT Knowledge Center

Oct 28th, 2:00 PM - 3:30 PM

\title{
Power-Broking From Brussels: Serbia, Kosovo Tensions Flex The EU's Foreign Policy Prowess
}

Ismet Hajdari

South East European University in Tetovo, ih21394@seeu.edu.mk

Follow this and additional works at: https://knowledgecenter.ubt-uni.net/conference

Part of the Journalism Studies Commons

\section{Recommended Citation}

Hajdari, Ismet, "Power-Broking From Brussels: Serbia, Kosovo Tensions Flex The EU's Foreign Policy Prowess" (2017). UBT International Conference. 202.

https://knowledgecenter.ubt-uni.net/conference/2017/all-events/202

This Event is brought to you for free and open access by the Publication and Journals at UBT Knowledge Center. It has been accepted for inclusion in UBT International Conference by an authorized administrator of UBT Knowledge Center. For more information, please contact knowledge.center@ubt-uni.net. 


\title{
Power-broking from Brussels: Serbia, Kosovo Tensions Flex the EU's Foreign Policy Prowess
}

\author{
Ismet Hajdari ${ }^{1}$ \\ ${ }^{1}$ South East European University (SEEU) Ilindenska 335, Tetovo 1200, Macedonia \\ (FRY) \\ ih21394@seeu.edu.mk
}

\begin{abstract}
The attractiveness of being a member of the EU for countries outside the Union has enabled the Union to begin demanding from candidate countries that they solve the problems they have with others, in particular their neighbours. Thanks to the appeal of its enlargement and conditionality as its main tool, the EU has started to play the role of a power brokering the rest of non-EU Europe. Particularly, the Brussels-guided dialogue between Kosovo and Serbia since March 2011 with the main goal of "normalizing" relations between the two has seen the EU shift to an authentic peacemaker. By applying a comparative study as well as deductive, partial analysis of official documents, the paper will argue that had it not been for the conditionality that the EU exercises towards Kosovo and Serbia, the relations between these two countries today would constitute a deep and frozen crisis. It will prove that the enlargement possesses in itself an extremely high potential not only to force candidate and aspiring countries for EU membership to implement European values, but also to constrain them in solving the problems and crises of bilateral and regional nature before getting a ticket for entry into the Union.
\end{abstract}

Keywords: EU, enlargement, Kosovo, Serbia.

\section{Introduction}

Before starting its wider expansion through Central and Eastern Europe after the fall of the Berlin Wall in 1989, the European Union considered the process of enlargement with new members mainly as an effective tool to promote internal reforms in EU candidate. This practice took a new form after the fall of communism and the codification of the enlargement criteria in Copenhagen in 1993, with the prospect of former communist countries gaining membership.

The attractiveness of being a member of the EU for countries outside the Union and their readiness "to do as they are told by Brussels" in order to join the European family has considerably increased the EU's influence and its room for manoeuvre in the rest of Europe out of the EU-territory. It has enabled the Union also to begin insisting from candidate countries to solve the problems they have with others, in particular, their neighbours, before becoming an EU member. Thanks to the appeal of its enlargement, rather than "foreign policy" in classical terms, the EU has started to play the role of a power broker, managing crises and unresolved issues outside the Union and legitimising itself in the role of a peacemaker outside the borders of its common area, respectively in the rest of non-EU Europe. 
During the early 2010s, the enlargement process for Serbia and Kosovo foresaw a Brussels-managed dialogue as a condition for accession negotiations, effectively plunging the EU in new and uncharted territory very different from its incipient goals - that of a power broker and negotiator, where the enlargement process once used for the aligning of political and economic interests could now serve as a tool for exercising EU diplomacy and the untangling of post-conflict disputes. EUmediated negotiations between Kosovo and Serbia ${ }^{104}$ have been taking place in Brussels since March 2011 with the main goal of "normalizing" relations between the two. By attempting to convince Kosovo and Serbia to solve the tense day-to-day disputes that characterize their relationship and making heavy use of the conditionality principle of "stick and carrot," the EU has shown that its policy of enlargement can also be successful when it has been placed in the service of the Union's foreign policy. Although still not over, the negotiations between Kosovo and Serbia have proved that enlargement itself can be used as a medium for resolving issues that are not strictly EU-related, but burden relations between EU candidate countries and potential candidates, and in the long term can have a negative on European security as a whole. In this way, the transformative power that the enlargement process provides to the EU over candidate countries has increased the political potential of the Union, in a way that other more "typical" power brokers such as the United Nations have been unsuccessful at achieving mainly due to their impotency in provoking real change in the countries and conflicts they are involved in.

This article intends to elucidate that -- if the binding power of the EU enlargement and its conditionality had not been used in the case of these two countries -- they would not have met voluntarily and discussed the disputes between them even though citizens on both sides continue to have a desperate need for such a thing. The paper, thus, aims to prove that the enlargement possesses in itself an extremely high potential not only to force candidate and aspiring countries for EU membership to reform themselves and implement European political, economic and legislative values, but also to constrain them in solving the problems and crises of bilateral and regional nature before getting a ticket for entry into the Union.

\section{A short overview of Kosovo-Serbia negotiations under EU mediation}

Negotiations between Kosovo and Serbia with EU mediation started in March 2011. At the beginning, they have had the character of technical negotiations for resolving bilateral disputes on the ground, which even twelve years after the Kosovo war have been preventing elementary cooperation between the two states. Technical negotiations at EU headquarters in Brussels were led by

${ }^{104}$ It has been the first negotiations between Pristina and Belgrade after the declaration of independence by Kosovo on February 17, 2008, respectively after the 1998-1999 war between the ethnic Albanian guerilla and Serbian security forces. Serbia has not recognized Kosovo's independence and had requested an advisory opinion on the issue from the International Court of Justice (ICJ). Following the decision of the ICJ in June 2010 that the declaration of Kosovo's independence was not against international law, Serbia and the EU presented in the same year to the General Assembly of the UN a draft resolution on launching negotiations between the two parties to resolve the outstanding issues between Kosovo and Serbia. The UN resolution was adopted on 9 September 2010 (http://www.un.org/press/en/2010/ga10980.doc.htm), but the beginning of the dialogue was postponed for the spring of 2011 due to early elections in Kosovo in the winter of 2010. 
senior government officials from both sides and they have been developed through seven rounds held in Brussels from March to October 2011. Negotiations were not easy. With an active and often compelling EU diplomacy, the parties have been persuaded to achieve much that was not even imaginable before their beginning, such as recognizing ID cards of the Republic of Kosovo by the border authorities of the Republic of Serbia or Serbia's disengagement from preventing Kosovo to join regional initiatives or to move towards the EU.

Technical negotiations between Kosovo and Serbia have been transformed into political negotiations later when the prime ministers of the two countries have begun to take part in them. None of the parties has published or arranged in an accessible way the agreements reached in Brussels. Such a lack of transparency may serve as the next testimony to the lack of readiness of each party to expose these agreements and their content to the public scrutiny. 105 The successful resolution of a series of open issues between the two parties, which over a decade have burdened and blocked the relations between the two states, has also created room for launching political dialogue between the two parties at a higher level as further issues on the negotiating agenda required greater "negotiating power" than the "technical" negotiators had. So, without concluding technical negotiations, Kosovo Prime Minister Hashim Thaçi and Serbian Prime Minister Ivica Dačić met on October 19, 2012 in the presence of EU foreign chief Catherine Ashton for the first time in the history of two states, opening the series of their ten consecutive meetings, which ended with the conclusion of the Brussels Agreement on 19 April 2013.106 Thaçi and Dačić's meeting was also the first meeting of the two countries' prime ministers after the Kosovo war 1989-1999. In addition to the importance of solving one of the biggest political disputes in Europe, achieving the highest possible political profile in the negotiations between Kosovo and Serbia also have had symbolic importance, because both prime ministers were actively involved in the Kosovo war: Thaçi as the political representative of the Kosovo Liberation Army (KLA), while Dačić as one of the prominent spokesmen of the regime of former Serbian President Slobodan Milosevic.

${ }^{105}$ The record of agreements reached between the two parties by June 2017 was prepared by the author of the paper and is based on the verbal pronouncements of the Kosovar and Serbian negotiators: 1. Agreement on freedom of movement across the border (with which Serbia partially has recognized personal documents of the Republic of Kosovo); 2. Agreement for submission of copies of civil registers and cadastres; 3 . Agreement on mutual recognition of university degrees; 4. Agreement on the recognition of Kosovo customs stamps by Serbia; 5. Agreement on the suspension of trade embargoes; 6. Agreement on integrated management of common border crossing points; 7. Agreement on representation of Kosovo in regional organizations; 8. Agreement on exchange of liaison officers between the two countries; 9. Agreement for the establishment of the multi-ethnic police unit in Kosovo for the protection of Serbian cultural heritage; 10. Agreement for establishment of a working group for the feasibility study of the Pristina - Nish highway; 11. Agreement for the establishment of the Special Fund for the North of Kosovo; 12. Telecommunication agreement; 13. Agreement on the justice system in the north of Kosovo and the extinction of Serbia's parallel structures ("civil defence"); 14. The reciprocity agreement on registration plates; 15 . Energy agreement; 16. Agreement for full revitalization of the Mitrovica Bridge and main road in northern Mitrovica.

${ }^{106}$ The full content of the Brussels Agreement is part of the Law No. 04 / L-199 on the ratification of this agreement, which the Kosovo Assembly approved on 27 June 2013: http://gzk.rksgov.net/ActDocumentDetail.aspx?ActID=8892 
In the period from October 2012 to April 2013 and with the mediation of than EU foreign chief Catherine Ashton, a total of 10 meetings between Thaçi and Dačić were held in the form of bilateral meetings or plenary sessions.107 Negotiations were kept behind closed doors, were not easy for both prime ministers and were over consuming. Based on the public appearances of the negotiators at home and in front of their public, it was seen that they did not possess the true political will and sincere readiness to negotiate as they presented the entire process as mandatory and justified it as a result of international pressure.108 Following the arrival of the Brussels Agreement in April 2013, Kosovo and Serbia's prime ministers have continued to meet with EU mediation not only with regard to new issues but also to implementing this agreement. Unofficially, it is said that the multiyear negotiation process between Kosovo and Serbia is planned to be crowned in the end with the signing of a reconciliation treaty between the two former foes. It is not excluded that a modus of Kosovo's "soft recognition" by Serbia would be achieved.

\section{Enlargement as an enforcement tool}

In the case of negotiations between Kosovo and Serbia for the normalization of their relations, the EU has increasingly used the enlargement as a mean of exercising its foreign policy and achieving its international goals. In the case of Kosovo and Serbia, the EU's main objective was the solution of perhaps the largest European dispute, which with its explosive potential could always generate the destabilization of the Balkan region, which is largely outside of the borders of the Union. Also, like never before, the EU has promoted itself as a power broker to initiate the reconciliation process between Kosovo and Serbia through the "softening" of the negotiating parties to settle disputes between them at the table and with political agreement. In doing so, enlargement has been the most powerful Brussels' card in convincing the both sides to take a seat at the joint table in March 2011 and launch the negotiations.

Thanks to the benefits that come with EU integration, unwillingness of Pristina and Belgrade to meet and negotiate was broken. ${ }^{109}$ Both sides have been made clear by the EU since that any their further integration step with the EU will be conditioned by constructive behaviour towards the opposite side, readiness for concessions and the need for concrete and positive outcome from the negotiations, on the basis of which each party's readiness to take a step forward towards the EU will be measured. As far as Kosovo is concerned, the "carrot" had consisted of two negotiating chapters,

107 http://www.b92.net/eng/news/politics.php?yyyy=2014\&mm=02\&dd=03\&nav_id=89195

${ }^{108}$ Criticizing public enterprises due to failure to maintain roads during the winter, Dačić said on December 11, 2002: "If I could meet with Thaci, they also could clean the snow." He added that there was no heavier decision like his "when he decided to talk to Thaci": http://www.novosti.rs/vesti/naslovna/aktuelno.290.html:410015-Dacic-Ako-sam-ja-mogao-sa-Tacijem-mogu-ioni-da-ociste-sneg - viewed on 07.01.2015. On the other hand, Thaci, reporting to the Kosovo Assembly on October 27, 2011 for the negotiations with Serbia, said that "dialogue on technical issues is a result of the international obligations that this Assembly has accepted. That is why the Kosovo government applies Kosovo's decisions."

${ }^{109}$ For the lack of willingness of both sides to meet, but also for the animosities that exist for each other in the opinions of the countries y, is also the fact that after their first meeting both Thaci and Dačic tried to bypass the answer to the question of journalists if they have tightened their hands:http://shqiptarja.com/news.php?IDNotizia=129525\&IDCategoria=2727 - e shikuar më 07.02.2015. 
which, at the time of talks with Serbia in Brussels, developed with the EU: the Stabilization and Association Agreement (SAA) and visa liberalization. Both negotiations constitute a major foreign policy interest of Kosovo, as they would lead to the first contractual relations between Pristina and Brussels. While, on the other hand, Serbia's negotiations with Kosovo have evolved during the time when the EU's decision to accept Serbia's EU candidate status was expected, respectively before the official launch of Serbia's accession talks with the Union. None of the negotiating parties has had a great deal of manoeuvring force to stubbornly oppose on EU insistence on reaching compromise on bilateral disputed issues.

The Brussels Agreement, as the first political agreement between Kosovo and Serbia in history, was not easily achieved even though it was clear to the parties that they would be able to count on "golden carrots" only if co-operative and if this co-operation reflects on concrete political agreements. The true degree and intensity of European pressure behind closed doors is little known and it can only be assumed on the basis of the negotiating parties' behaviour in front of the public when they return home and presented stubborn justification for the need to continue the dialogue, which, on the other hand, has not enjoyed much political support and understanding in the opinion of the two countries. This only indicates that the Albanian and Serbian negotiators havebeen caught in the middle: to accept the compromise that the EU had had put on the table and to secure the unimpeded progress of their countries towards the Union or to reject the compromise lobbied by the EU, thus condemning themselves to return to a Europe's slum. The extent to which the negotiations between Pristina and Belgrade were "managed" by Brussels was evidenced by the decisions of the Union, which followed the Brussels Agreement. Only three days after its signing "closing down one of the chapters complicated by the collapse of Yugoslavia", ${ }^{110}$ the EU has announced the reward. The European Commission has recommended opening negotiations with Serbia for EU accession, while for Kosovo opening negotiations for the signing of the SAA.

Although Kosovo-Serbia negotiations are currently half-way, and it is not yet certain that two countries will finally sign the peace treaty, which is the ultimate goal of the negotiations, their example today can serve as a convincing illustration for instrumentalisation of enlargement in the service of EU foreign policy. The EU has never used the 'carrot' of enlargement so directly in order to achieve its foreign policy goals, as it was the case with negotiations between Kosovo and Serbia. In the case of negotiations between the two big Balkan enemies, enlargement has not only served to resolve disputes between aspirant countries for the EU's membership (after the accession of divided Cyprus, the EU does not want to import any other political, territorial or ethnic dispute with the admission of new members) but, at the same time and very efficiently, the EU has demonstrated its crisis management capacity on the continent and to maintain European security. On the occasion of Kosovo-Serbia negotiations and the achievement of the historic April 2013 agreement between Kosovo and Serbia, the EU has played a role she dreams and intends on her foreign policy: to be a global player. "By relying on full membership incentives, the EU is able to exert major influence on the domestic affairs of the countries that apply. It can even be considered as one of the most visible and effective instruments of the EU in foreign affairs," said Thomas Mehlhausen.

110 http://eeas.europa.eu/top_stories/2013/190413_eu-facilitated_dialogue_en.htm 


\section{Enlargement as a limitation of the sovereignty of the candidate countries}

Among a large number of authors, imposing EU standards and criteria on candidate countries as a condition for getting closer to the Union is increasingly commented on as a significant departure from the so-called "sacred" principle of international relations on state sovereignty and noninterfering in their internal affairs. "EU enlargement is, in itself, a form of the EU foreign policy. It puts the EU in a position to model internal and external policies of the applicant countries. Traditional principles of non-interference in the internal affairs of other states appear to be set aside in this process." 111 She added that "expansion is intended to include external actors" and that through this EU "teaches with family life" states that are outside of the EU. ${ }^{112}$

The negotiation practice that the EU exercised with the candidate countries in the fifth enlargement (ten Eastern European countries joined the EU in 2004, while Romania and Bulgaria in 2007) developed following the codification of all rules and standards in the form of EU's Acquis Communautaire at the summit of the EU Council in Copenhagen in 1993. It has given Brussels a powerful weapon to limit the manoeuvring space for the exercise of will by candidate countries in their relations with the EU. Ahead of the fifth enlargement, the EU faced the major challenge of substantial transformation of ex-communist societies through the reorganization of economic life, privatization, the establishment of a free market and the establishment ofconstitutional democracies in these countries. This required much greater and more substantial EU focus on the negotiation process as well as the definition of more comprehensive and more precise conditions for those aspiring to become part of the EU. Since 1993, candidate countries simply do not have much manoeuvring space to override or mitigate membership criteria nor to determine the duration of the negotiations. Decisions on the success or failure of candidate countries in the passage of tests are issued in Brussels, while the whole negotiation process between the EU and the candidate country consists mainly of evaluating candidate progress in adapting it to the Union system as a condition for become his member. In the academic community it can often be heard that, in essence, it is not about negotiations, but about a one-way process where a party sets "rules of the game", while the other "plays" according to them. Trying to explain the power the EU has in the enlargement process over the candidate countries, Dimitrova says that relations between the EU and candidate countries since 1993 can be termed as "enlargement governance".113 According to her, governance through enlargement turns the negotiation process between the EU and the candidate countries into an "asymmetric process", which places the candidates in the position of adopting the rules that are set by the EU."114 Linked to this, perhaps the most prominent feature of EU governance through enlargement is the inclusion of conditionality. The (current) conditionality overview shows the culmination of its use in relations between European states. The EU has already begun to use

\footnotetext{
111 "Enlargement and the Common Foreign and Security Policy: Transforming the EU's External Policy?" Helene Sjursen, The University of Oslo: http://www.sv.uio.no/arena/english/research/publications/arenapublications/workingpapers/working-papers1998/wp98_18.htm.

$112 \mathrm{http} / / /$ www.sv.uio.no/arena/english/research/publications/arena-publications/workingpapers/workingpapers1998/wp98_18.htm .

${ }^{113}$ Antoaneta L. Dimitrova "Enlargement Governance and Institution Building in Central and Eastern Europe: The Case of the European Union's Administrative Capacity Requirement": http://ecpr.eu/Filestore/PaperProposal/ae34171a-929c-4e6a-ac61-f732c8909c50.pdf

114 Ibid.
} 
conditionality in the first and second generation agreements with the candidate countries. Conditioning is already a feature of the assistance provided under the PHARE program, which is the main mean of financial support for Central and Eastern Europe, "Dimitrova said.115

Otherwise, there are even more negative projections of EU enlargement policy. Oxford University Professor Jan Zelonka, says that the EU places "imperial" control over the less-stabilized parts of Europe. "This effort is truly imperial in the sense that the EU tries to impose internal restrictions on other actors, through various forms of economic and political domination, or even through formal annexation efforts," he says. ${ }^{116}$

\section{Conclusion: Enlargement as EU's foreign policy tool}

The EU's enlargement policy has managed to convince the two former enemies, Kosovo and Serbia, to launch efforts to find solutions to bilateral problems at the table, for the first time since the outbreak of the crisis in relations between them. Even, by taking on the role of the mediator and the main facilitator for these talks, the EU has managed to turn the negotiating parties towards the first political agreement between them. This agreement sets the foundation for new progress in the relationship between former enemies, which, according to unofficial announcements, should end in signing the peace and reconciliation treaty. At all times during the negotiations, the EU has exercised a policy of conditionality on the negotiating parties according to the principle "take or run away". The EU's rapid positive reaction only three days after the Brussels agreement that rewarded Kosovo and Serbia with the opening of the European integration perspective for both countries, could serve as a basis for the conclusion that the EU's enlargement policy functions according to the formula "implementation through reward".

The European perspective in the case of Kosovo and Serbia has also played the role of the motor force for the negotiating parties to co-ordinate with the negotiating agenda, which the EU has offered since there was not at all a political climate among the negotiating parties for reaching agreement.

The Brussels agreement is one of the biggest EU external successes. With this agreement, the EU has also demonstrated its capacity to manage and to endorse latent conflicts, just as it was between Kosovo and Serbia. Thanks to this agreement, on the other hand, the EU has regain confidence that it can play a more important political and diplomatic role on the European stage, trying to get for the Union the political role similar to the one it plays as a giant in the economy and world trade.

The Kosovo-Serbia agreement will be one of the biggest assets and arguments of those in the EU that sees the Union not only as a mechanism for accommodating its members, but as an "empire" of values and standards, intended to play the role global in defining the pattern by which inter-state and international relations should be regulated. Immediate challenges for such a role that are brought before the EU are immediately in the neighbourhood of Kosovo and Serbia: Macedonia with the growing political frustration of the Albanian community there because of obstructions in the implementation of the Ohrid Agreement; Bosnia and Herzegovina with the paralysis of the system

\footnotetext{
115 Ibid.

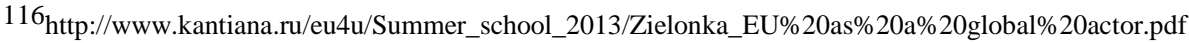


that the Dayton Accords produces; as well as many other internal or bilateral issues (especially those related to minorities) which, although at a lower risk, have destabilizing potential in the EU process to restore the Balkans to Europe. 


\section{Reference:}

1. Mehlhausen T. (2002), New Approaches to EU Foreign Policy, Routledge, London,

2. Dimitrova AL. (2010) Enlargement Governance and Institution Building in Central and Eastern Europe: The Case of the European Union's Administrative Capacity

Requirement, Leiden University, Leiden.

3. Sjursen E. (1998), Enlargement and the Common Foreign and Security Policy: Transforming the EU's External Policy, ARENA, Oslo.

4. http://noa.al/artikull/post/305479.html.

5. http://www.b92.net/eng/news/politics.php?yyyy=2014\&mm=02\&dd=03\&nav_id=89195

6. http://www.novosti.rs/vesti/naslovna/aktuelno.290.html:410015-Dacic-Ako-sam-jamogao-sa-Tacijem-mogu-i-oni-da-ociste-sneg

7. http://shqiptarja.com/news.php?IDNotizia=129525\&IDCategoria=2727

8. http://eeas.europa.eu/top_stories/2013/190413_eu-facilitated_dialogue_en.htm

9. http://eeas.europa.eu/top_stories/2013/190413_eu-facilitated_dialogue_en.htm

10. http://www.sv.uio.no/arena/english/research/publications/arenapublications/workingpapers/working-papers1998/wp98_18.htm

11. http://ecpr.eu/Filestore/PaperProposal/ae34171a-929c-4e6a-ac61-f732c8909c50.pdf

12. http://www.kantiana.ru/eu4u/Summer_school_2013/Zielonka_EU\%20as\%20a\%20global $\% 20$ actor.pdf

13. http://www.un.org/press/en/2010/ga10980.doc.htm 